Maja P. Miličević Petrović*

$371.3:: 81 ’ 243$

Универзитет у Београду

https://doi.org/10.18485/analiff.2019.31.1.10

Филолошки факултет

Originalni naučni rad

Jelena V. Grubor

Državni univerzitet

Primljen: 16.04.2019

u Novom Pazaru

Prihvaćen: 11.06.2019

\title{
INPUT I POSTIGNUĆE U USVAJANJU STRANOG JEZIKA
}

Opšte uverenje i u teoriji i praksi jeste da input igra važnu ulogu prilikom usvajanja stranog/drugog jezika (J2). Uprkos naglašenoj teorijskog podeljenosti u odnosu na ulogu koju mu dodeljuju, stručnjaci su saglasni u tome da se jezik ne može usvojiti bez izloženosti inputu. U skladu sa tim, cilj našeg rada je da na osnovu pregleda relevantne literature iz oblasti usvajanja J2 ukažemo na probleme sa kojima se istraživači susreću pri ispitivanju inputa i njegove povezanosti sa postignućem, da na osnovu zaključaka analize predložimo moguće pravce budućih istraživanja, kao i da istaknemo moguće implikacije za nastavu stranih jezika. U radu zaključujemo da je potrebno pomeranje paradigme ka kompleksnijim modelima inputa u teorijskom smislu, uvođenje rigoroznijeg merenja inputa i postignuća u metodološkom, kao i direktno uvrštavanje naučnih saznanja iz empirijskih istraživanja u nastavne udženike i nastavničke priručnike u praktičnom smislu.

Ključne reči: input, J2, postignuće, strani jezik.

\section{Uloga inputa u usvajanju J2: Uvodne napomene}

Input predstavlja jednu od centralnih komponenti iskustva usvajanja jezika. Može se definisati kao ,,jezik koji učenici čuju ili vide i na osnovu

*\$m.milicevic@fil.bg.ac.rs. 
koga mogu da nauče neki sadržaj” (Richards \& Schmidt, 2010: 286). ${ }^{1}$ Drugim rečima, čine ga ,sirovi” jezički podaci kojima su učenici izloženi i iz kojih izvode zaključke o značenju i strukturi ciljnog jezika (Chaudron, 1985; Carroll, 2001). Nijedan jezik ne može se usvojiti bez odgovarajućeg inputa (Gass, 1997), što ga je dovelo na mesto jednog od glavnih faktora kojima se u proučavanju usvajanja jezika posvećuje pažnja. Međutim, iako se i međusobno vrlo različiti teorijski pristupi slažu u pogledu toga toga da je input neophodan za usvajanje, uloge koje mu pripisuju vrlo su različite, a tačan odnos između odlika inputa i uspeha postignutog u savladavanju ciljnog jezika i dalje je nepotpuno razjašnjen. ${ }^{2}$

U okviru opštih teorija usvajanja drugog/stranog jezika $(\mathrm{J} 2)^{3}$ na jednom polu je stanovište da je najuticajniji faktor u procesu usvajanju priroda (eng. nature), dok je na drugom shvatanje zasnovano na presudnom značaju okruženja (eng. nurture). Prvi, nativistički pol podrazumeva da je usvajanje jezika zasnovano na urođenom znanju određenih jezičkih pravila i kategorija, kao i pratećem apstraktnom mehanizmu za usvajanje koji je specijalizovan za jezik (eng. language acquisition device). Nativisti smatraju da je input bitan za izbor između različitih gramatičkih opcija koje dozvoljava urođeno znanje (kao deo univerzalne gramatike), ali da ne može sâm objasniti proces usvajanja, pre svega zbog svog nesavršenstva. ${ }^{4}$ „Argument o siromaštvu inputa" (eng. poverty of the stimulus) centralni je deo nativističkog viđenja usvajanja jezika uopšte i podrazumeva shvatanje da input sadrži manje informacija o jeziku nego što ih govornici usvajaju, te da moraju postojati dodatni izvori znanja (v. npr. Chomsky, 1981). Autori koji veruju da univerzalna gramatika nije direktno dostupna u J2 (npr. Bley-Vroman, 1990) stoga očekuju da se kod učenika razvije „divlja” gra-

1 "language which a learner hears or receives and from which he or she can learn" 2 Carroll (2001: 2) ističe da je uverenje da je jezik nemoguće usvojiti bez izloženosti inputu jedno od vrlo retkih oko kojih se slažu svi istraživači u oblasti.

3 Termini ,drugi” i/ili ,strani” jezik u literaturi se obično zamenjuju neutralnom univerzalnom oznakom L2, poteklom od engleskog second language (v. npr. Grubor, 2015: 141). U ovom radu, koristićemo srpski prevodni ekvivalent $J 2$ za situacije kada se ne insistira na razlici između konteksta učenja jezika (za razliku između drugog i stranog jezika v. npr. Gass \& Selinker, 2008: 7).

4 Ovakav prikaz nativističkog viđenja inputa pojednostavljen je u svrhu poređenja sa suprotstavljenim shvatanjima. Značaj koji se u nativističkoj paradigmi pridaje inputu zapravo je različit od pristupa do pristupa i od istraživača do istraživača (v. npr. Slabakova, Leal, \& Liskin-Gasparro, 2014; Rankin \& Unsworth, 2016). 
matika, odnosno jezički sistem koji narušava ne samo pravila ciljnog $\mathrm{J}$ 2, već i univerzalna pravila strukture ljudskog jezika. Nasuprot tome, pristalice kognitivističkog viđenja jezika veruju da lingvističko okruženje ključno doprinosi usvajanju, koje zapravo predstavlja apstrahovanje pravila iz statističkih raspodela jezičkih jedinica u inputu (v. Ellis, 2002a; Bybee, 2008). ${ }^{5}$ Dodatno se može istaći i kompromisni stav zasnovan na ideji da je za usvajanje jezika presudan širi društveni kontekst, a pre svega socijalna interakcija. Ovo viđenje se nadovezuje na obuhvatniju sociokulturnu teoriju Lava Vigotskog, koja počiva na ideji da deca razvijaju misaone funkcije u interakciji sa kompetentnijim osobama iz sociokulturnog okruženja, i da unutar tog (asimetričnog) odnosa osoba nižih kompetencija postepeno internalizuje više mentalne funkcije (Vigotski, 1974). Gledano iz ove perspektive, gde su više mentalne funkcije internalizovani oblici socijalne interakcije, posebno jezika (Vygotsky, 1991), input je neophodan za usvajanje jezika, ali je presudno da se dobija u okviru smislenih interakcija.

Unutar svake od širih teorija postoji niz pristupa bliže posvećenih inputu. ${ }^{6}$ Neki od njih fokusirani su na mehanizme putem kojih se input analizira i pretvara $u$ (nova) znanja o ciljnom jeziku, dok se drugi koncentrišu na odnos inputa i uspešnosti u usvajanju, odnosno postignuća. Prva tema je aktuelna i za domen usvajanja jednog maternjeg jezika, dok je druga predmet interesovanja pre svega u višejezičnim situacijama, gde postoji velika varijabilnost u ishodu usvajanja, bilo da se radi o simultanom dvojezičnom usvajanju ili usvajanju J2. Međutim, ove teme zapravo nisu potpuno odvojene jedna od druge. U izučavanju inputa relativno rano se uvidelo da za utvrđivanje veze sa postignućem nije dovoljno posmatrati input kao objektivno merljiv sklop stimulusa koji se vizuelno ili auditorno opažaju (što predstavlja dominantno viđenje; v. Carroll, 1999: 341). Tačnije, analizom inputa kome je učenik izložen ne mogu se u potpunosti razotkriti mehanizmi koji su u osnovi usvajanja. Ovo je još sredinom prošlog veka uočio Corder (1967), koji je istakao da pûko prezentovanje određene lingvističke jedinice nije dovoljno za njeno usvajanje i da ne postaju sve

5 Među nazivima za ovu grupu pristupa sreću se i ,emergentizam” i „pristupi zasnovani na jezičkoj upotrebi" (eng. usage-based approaches; v. npr. Mitchel, Myles, \& Marsden, 2013: 99). Pre savremenih kognitivističkih teorija input je posmatran kao ključni faktor i u biheviorizmu (Skinner, 1957).

6 Pojedini modeli isključivo se povezuju sa određenom širom teorijom usvajanja, dok su drugi kompatibilni sa vise širih teorijskih pristupa (v. npr. VanPatten, 2015: 131). 
informacije koje su učenicima na raspolaganju deo njihovog (međujezičkog) gramatičkog sistema. Neophodno je da postoje i uslovi koji omogućavaju da objektivno prisutni input pređe u intejk (eng. intake), odnosno ,analizirane" podatke (Carroll, 1999), a zatim i u trajnije strukture međujezika. Corder je kao najznačajniji faktor za prelazak inputa u intejk video pažnju, ${ }^{7}$ i premda nije bliže razradio model njenog funkcionisanja (detaljnije u Carroll, 1999: 342-344), za dalja istraživanja veliki značaj je imalo njegovo ukazivanje na to da odnos između inputa i postignuća nije nužno direktan i da uticaj inputa ne treba posmatrati kao isključivo spoljašnji faktor, već kao spregu između eksternih draži i učeničkog internog sistema.

Polazeći od ovakve slike, cilj našeg rada jeste analitički osvrt na literaturu direktno ili indirektno posvećenu odnosu između inputa i postignuća u usvajanju stranog jezika u učionici, uz ukazivanje na glavne probleme sa kojima se istraživači susreću i uz predlaganje pravaca za buduća istraživanja. Fokus, dakle, nije na detaljnom pregledu pojedinačnih istraživanja i evaluaciji njihovih rezultata, već na opštijem kritičkom prikazu različitih teorijskih pristupa i teorijskih i empirijskih problema. Naglasak stavljamo na učionicu zbog toga što se radi o kontekstu u kome se saznanja istraživanja mogu najdirektnije primeniti u svrhu povećanja uspešnosti usvajanja jezika. Međutim, ne ograničavamo se na istraživanja koja se bave prilagođavanjem inputa, pa naš rad ne potpada potpuno pod oblast usvajanja J2 u učionici (eng. instructed second language acquisition), koja ima kao centralnu temu uticaj nastave na usvajanje (dok ostale teme deli sa usvajanjem J2 uopšte; v. VanPatten, 2017), već širem polju usvajanja J2. Prihvatajući mišljenje koje iskazuju VanPatten i Cadierno (1993: 46), pod inputom podrazumevamo isključivo jezički materijal u kome je iskazano značenje, dok iz pregleda isključujemo radove posvećene korektivnoj povratnoj informaciji.

Budući da je jedan od osnovnih problema $u$ ispitivanju inputa njegova teška merljivost, u radu polazimo od pregleda načina na koji se input operacionalizuje u empirijskim istraživanja usvajanja J2; na sličan način govorimo i o postignuću. Zatim dajemo prikaz relevantnih teorijskih pristupa i rezultata do kojih su istraživanja u okviru ovih pristupa došla. Najzad, u skladu sa zaključcima analize, predložićemo mogući pravac budućih istraživanja i naglasiti moguće implikacije za nastavu stranih jezika.

$7 \quad$ U kasnijim istraživanjima pored opšte uloge pažnje ističe se i značaj usmeravanja pažnje, odnosno primećivanja inputa (eng. noticing; v. Schmidt, 1990). 


\section{Input i postignuće: problemi merenja}

Empirijski lako uočljiva varijabilnost u uspešnosti usvajanja J2 vrlo je rano postavila u centar pažnje istraživanja faktore koji utiču na postignuće. Input je jedan u nizu takvih faktora, interesantan i praktično, budući da se u velikoj meri može kontrolisati i prilagoditi tako da doprinese postignuću, za razliku od (relativno) nepromenljivih faktora poput individualnih karakteristika učenika i šireg društvenog okruženja. U usvajanju stranog jezika značajan deo inputa predstavlja nastavni input, odnosno materijal kome su učenici izloženi u učionici. Međutim, budući da je u današnjem globalizovanom svetu lako dostupan autentičan materijal na velikom broju jezika, vannastavni input takođe igra važnu ulogu.

\subsection{Merenje inputa}

Ispitivanje inputa deluje gotovo paradoksalno: jasno je da input mora uticati na uspešnost u usvajanju J2, ali on je istovremeno i jedna od najteže merljivih komponenti usvajanja. Iako naizgled predstavlja jasnu objektivnu veličinu, input je direktno i potpuno merljiv jedino u idealizovanim sredinama i hipotetičkom vakuumu u kome istraživač sve vreme ima uvid u jezički materijal kome su učenici izloženi. Na primer, input je moguće u potpunosti kontrolisati i meriti, barem kratkotrajno, u istraživanjima koja se služe veštačkim jezicima (v. Friederici, Steinhauer, \& Pfeifer, 2002) ili ispituju početne faze usvajanja nepoznatih jezika (v. Gullberg, Roberts, i dr., 2010; Carroll \& George, 2018). Van ovakvih situacija, nemoguće ga je ekstrahovati u potpunosti, ne samo zbog praktičnih i etičkih problema koji bi se javili pri eventualnim pokušajima dugotrajnijeg snimanja učionice, već i zbog toga što su učenici izloženi jeziku kroz različite dodatne medijume i situacije. Budući da je najčešće nemoguće izdvojiti i izmeriti celokupan input, u istraživanjima se on operacionalizuje na različite indirektne načine, koji u najvećoj meri zavise od toga da li je cilj istraživanja proučavanje inputa uopšte, ili inputa vezanog za konkretan jezički fenomen.

Kada je reč o inputu uopšte, istraživanja u kojima se on meri u usvajanju stranog jezika srazmerno su retka. U njima se uglavnom traži način da se kvantifikuje količina inputa, pri čemu se zasebno posmatraju nastavni (koji potiče od nastavnika, nastavnog materijala i drugih učenika; ${ }^{8} \mathrm{v}$.

8 Input koji se dobija od drugih učenika najčešće se zanemaruje u istraživanjima, uglavnom zbog svesti o prisutnom većem broju grešaka, iako postoje istraživanja koja 
Gass \& Selinker, 2008: 369) i vannastavni input. Takođe se može napraviti razlika između tekućeg inputa, koji se odnosi na vremenski period koji istraživač odredi kao relevantan (npr. poslednjih godinu dana; v. Grubor, 2018 za vannastavni input), i ukupnog ili kumulativnog (Unsworth, 2013) inputa, koji se računa za celokupni period izloženosti ciljnom jeziku. Zatim, fokus prilikom merenja može biti na dužini vremena tokom koga su učenici bili izloženi inputu (npr. Grubor, 2012 za nastavni input beleži broj časova na nedeljnom i godišnjem nivou), ili na broju jezičkih jedinica (reči, iskaza, jedinica posvećenih određenoj veštini, i slično) kojima su učenici izloženi. Takođe je značajno odrediti da li će dobijene mere biti iskazane apsolutno (npr. kao ukupan broj sati ili broj jezičkih jedinica) ili relativno (npr. u vidu procentualne zastupljenosti različitih jezičkih jedinica).

Usled toga što se u njih najčešće ne može ostvariti neposredan uvid, podaci o navedenim tipovima inputa uglavnom se dobijaju putem upitnika i/ili skala procene koje popunjavaju sami učenici, a na mlađim uzrastima njihovi roditelji ili nastavnici. Kod skala procene uobičajeno je da se količina inputa izražava na ponuđenim višestepenim skalama na kojima učenici beleže učestalost kontakta sa, na primer, različitim izvorima vannastavnog inputa (sagovornicima, knjigama, muzici i slično; v. Grubor, 2018; Sundqvist, 2009). ${ }^{9}$ Dodatnu opciju predstavljaju namenski učenički dnevnici. Na primer, Sundqvist (2009) je koristila dnevnike u koje su učenici u dva navrata tokom školske godine po nedelju dana zapisivali sve detalje o kontaktu sa knjigama, pesmama, filmovima, televizijskim emisijama, kako na engleskom (predmet rada bio je vannastavni engleski jezik), tako i na maternjem švedskom i eventualnim drugim jezicima. Učenički odgovori se kod ovakvih instrumenata uobičajeno predstavljaju kroz relativne mere (npr. procenat učenika koji često razgovaraju sa izvornim govornicima), ili kroz prosečne vrednosti skala.

Uvid u nastavni input može se ostvariti i snimanjem časova ili pregledanjem nastavnih materijala. Snimci časova mogu dati dragocene informacije o opštijim merama kakve su ukupan ili prosečan broj reči u inputu koji daje nastavnik (v. npr. Bowers \& Vasilyeva, 2011). Kod pregledanja nastavnih materijala tipično je da se u prikupljenom materijalu broje razli-

pokazuju da učenici ne uče pogrešne oblike jedni od drugih (Gass \& Selinker, 2008: 369). 9 Slični upitnici/skale procene u upotrebi su i u izučavanju inputa u simultanoj dvojezičnosti. Oni se u literaturi obično nazivaju „roditeljskim upitnicima” (v. npr. Pearson, Fernandez, i dr., 1997; Unsworth, 2013). 
čite jedinice, često uz konsultovanje sa nastavnicima. Na primer, Grubor (2012) analizom sadržaja izdvaja gramatičke jedinice i jedinice posvećene različitim jezičkim veštinama, a zastupljenost različitih jedinica nastavnog inputa se zatim iskazuje procentualno u odnosu na ukupni input, uz izračunavanje prosečnog broja jedinica inputa po času.

U istraživanjima koja se fokusiraju na usvajanje konkretnih leksičkih ili gramatičkih pojava moguće je merenje učestalosti datih pojava u snimcima časova ili nastavnim materijalima. Na primer, Horst (2010) proučava mogućnosti za usvajanje novih reči u engleskom jeziku kroz leksičko profiliranje korpusa nastavničkog govora snimljenog tokom devet nedelja nastave (zaključujući da se nove reči ne ponavljaju dovoljan broj puta da bi situacija za usvajanje bila optimalna). Ponekad se pribegava i proučavanju uzoraka jezika za koje se pretpostavlja da adekvatno predstavljaju input kome su učenici izloženi, iako ti uzorci nisu uvek stvarni input sa kojim su učenici bili u kontaktu. Posebno često se u ovakvim situacijama koriste opšti korpusi ciljnog jezika, uz pretpostavku da učestalost proučavanih pojava u njima odgovara onoj u inputu koji učenici dobijaju. Tako Miličević (2007) koristi referentne korpuse italijanskog, engleskog i srpskog jezika za proveru učestalosti upotrebe različitih refleksivnih i recipročnih markera (poput se i sam sebe/jedan drugog) uz različite glagole, uz dalje proučavanje veze između dobijenih učestalosti i postignuća učenika merenog procenama prihvatljivosti različitih kombinacija glagola i refleksivnih/recipročnih markera.

Najzad, u brojnim istraživanjima meri se i kvalitet inputa, kroz indikatore poput toga od koga input potiče (izvornih govornika, nastavnika ili drugih učenika) i da li je prilagođen učenicima (kao vid ,nastavničkog govora” ili ,govora za strance”) ili autentičan. Moguće je i računanje opštih tekstualnih mera poput leksičkog bogatstva (izraženog npr. kroz broj različitih reči) i strukturne složenosti (npr. prosečne dužine rečenice) (v. npr. Bowers \& Vasilyeva, 2011). Poseban tip ispitivanja kvaliteta nastavnog inputa predstavljaju istraživanja kontrolisanog inputa koji se namenski osmišljava i koristi u studijama zasnovanim na intervencijama u nastavi (v. npr. VanPatten \& Cadierno, 1993, kao i brojna istraživanja citirana u daljem toku rada). U ovakvim istraživanjima ne meri se spontano nastali input, već se planiraju vrste inputa (s obzirom na način prilagođavanja, prisustvo/odsustvo interakcije, i slično) koje će učenici dobiti, kako bi se utvrdilo kakav input dovodi do najvećeg postignuća. 


\subsection{Merenje postignuća}

Postignuće, odnosno stepen ovladavanja stranim jezikom, predstavlja veoma složen i nejedinstven konstrukt. Može se govoriti o opštem postignuću, ali i o postignuću s obzirom na pojedinačne jezičke nivoe ili veštine (npr. morfosintaksu i leksiku, ili razumevanje i pisanje), kao i s obzirom na konkretne jezičke jedinice ili gramatičke pojave (npr. izražavanje prošlog vremena ili morfološko označavanje množine imenica).

Najveći izazov za operacionalizaciju i merenje predstavlja opšte postignuće, odnosno opšte znanje stranog jezika. Thomas (1994: 330) određuje opšte znanje kao „ukupnu jezičku kompetenciju neke osobe i njenu sposobnost jezičke realizacije na drugom jeziku"10. Merenje opšteg postignuća zapravo predstavlja određivanje opšteg nivoa znanja učenika, pri čemu se nivo najčešće ne iskazuje u vidu kategorija (početni, srednji, i slično), već kao rezultat ostvaren na primenjenom mernom instrumentu, a rezultati učenika se uglavnom ne porede sa rezultatima koje na istom instrumentu ostvaruju izvorni govornici, što je van istraživanja inputa uobičajeno (v. Kraš \& Miličević, 2015).

U kontekstu učionice, opšte postignuće se može meriti na različite načine (za detaljniji pregled v. Hulstijn, 2015): ostvarenim ocenama (na ispitu ili tokom školske nastave), testovima koje osmišljavaju nastavnici, kao i eksterno osmišljenim testovima, koji su u nekim slučajevima standardizovani (npr. TOEFL za engleski jezik), odnosno porede učinak učenika sa rezultatima većeg broja drugih učenika (Collier, 1989: 517). ${ }^{11}$ Testovi opšteg postignuća mogu sadržati i pojedinačne zadatke posvećene različitim jezičkim veštinama i različitim jezičkim nivoima (Grubor, 2012), ili biti u formatu cloze testa (Miličević, 2007). Najzad, postignuće se, nešto ređe, meri i kroz subjektivne procene samih učenika ili njihovih nastavnika, najčešće putem skala Likertovog tipa (Butler \& Lee, 2006).

Zadatke za ispitivanje postignuća u usvajanju pojedinačnih pojava nemoguće je nabrojati - u ovu svrhu mogu se upotrebiti svi tipovi zadataka koji se inače sreću u eksperimentalnim istraživanjima usvajanja J2 i u testiranju usvojenosti individualnih fenomena u učionici (procene prihvatljivosti, vođena produkcija, zadaci povezivanja slika, itd.). Ovakve zadat-

10 "a person's overall competence and ability to perform in L2"

11 Up. situaciju u proučavanju simultane dvojezičnosti, gde se najčešće koriste standardizovani testovi jezičkog razvoja (v. npr. Unsworth, u štampi). 
ke učenici često rade nakon izlaganja kontrolisanom inputu čiji se efekti ispituju, u nekim slučajevima samo neposredno posle, a nekada i u okviru odloženog testiranja (v. pregled u Benati, 2016, 2017). ${ }^{12}$

Podaci o postignuću mogu se korelirati sa podacima o količini inputa, posebno kada se ispituje opšte postignuće. Ovakav pristup posebno je čest $u$ istraživanjima simultane dvojezičnosti, a zanimljivo je primetiti i da u kontekstu usvajanja stranog jezika nedostaju istraživanja koja se bave određivanjem praga, odnosno količine inputa koja je dovoljna za usvajanje, iako je efekat praga dobro poznat iz radova o simultanoj dvojezičnosti - povećanje količine inputa korelira sa višim postignućem do određenog praga, nakon koga dalji efekti izostaju (v. Unsworth, u štampi).

Kada je reč o usvajanju konkretnih jezičkih pojava, postignuće se često meri kao tačna upotreba određene jezičke jedinice izražena procentualno (v. Gathercole, 2002; Jia \& Fuse, 2007), a najveći deo istraživanja uključuje kao meru postignuća produkciju i test gramatičke ispravnosti (v. npr. Nicoladis, Palmer, \& Marentette, 2007; Pérez-Leroux, Pirvulescu, \& Roberge, 2009). Kada se meri postignuće u domenu užih pojava, česti su i eksperimentalni nacrti u kojima više grupa učenika dobija različitu vrstu modifikovanog inputa, pa se zatim ispituje koji tip inputa je najefikasniji, kratkoročni i/ili dugoročno (primeri ovakvih istraživanja navode se u daljem toku rada).

\section{Uticajni teorijski pravci u istraživanju inputa}

Uprkos kompleksnosti merenja, input je već dugi niz godina jedna od najispitivanijih varijabli u usvajanju J2 i brojni teorijski modeli posvećeni su upravo njegovoj obradi i njegovom delovanju na postignuće. U ovom odeljku grupišemo relevantne radove u tri šira pravca istraživanja: 1) interakcijska istraživanja, 2) modeli procesiranja inputa, i 3) drugi pristupi.

\subsection{Interakcijska istraživanja}

Jedna od dužih tradicija u proučavanju inputa poseban značaj pridaje komunikativnom kontekstu u kome se input dobija, odnosno interakci-

12 U velikom broju istraživanja postignuće se testira i pre nastavne intervencije, kako bi se kontrolisalo predznanje učenika i kako bi se utvrdilo da li su grupe koje se porede zaista uporedive. 
Maja P. Miličević Petrović / Jelena V. Grubor

ji učenika sa drugim govornicima ciljnog jezika (Gass, 2003; Gu, 2018). Među idejama koje se vezuju za početke interakcijskih istraživanja ističe se Krašenova hipoteza o inputu (Krashen, 1982, 1985), kao jedna od pet fundamentalnih hipoteza kojima se opisuje model kontrolnog mehanizma ${ }^{13}$ (Richards \& Rogers, 2015: 181-183), odnosno kao alternativni naziv samog modela (v. npr. Littlewood, 2004: 515-516). Ovaj model pretpostavlja da je za usvajanje jezika neophodno da učenici budu izloženi razumljivom inputu, odnosno jeziku koji je za jedan nivo iznad nivoa trenutnog znanja učenika. U jednoj od verzija (Krashen, 1983) uvodi se i koncept „uočavanja informacione praznine" između optimalnog inputa (inputa koji je za jedan nivo viši od trenutnog nivoa znanja učenika, što se iskazuje formulom $i+1)$ i metajezičkog pravila kojim učenik trenutno vlada. ${ }^{14}$ Koncepti koje je Krašen uveo u teoriju usvajanja J2 vrlo su uticajni i koriste se i danas, ali se Krašenu zamera odsustvo jasno operacionalizovane definicije razumljivog inputa, kao i istraživanja koja empirijski ispituju njegovu vezu sa postignućem.

U istraživanjima koja su usledila veliki broj istraživača počeo je naglašenije da zagovara ideju da nije dovoljno da učenici budu izloženi inputu, koliko god optimalan on bio, već da je uz to potrebna direktna lingvistička interakcija (Johnson \& Johnson, 1999: 186). Prema ovom pristupu, veliki broj faktora utiče na tok usvajanja jezika zajedno sa inputom, usled činjenice da je učenje jezika podstaknuto komunikativnim pritiskom, a u samom procesu ti faktori se međusobno uslovljavaju i modifikuju jedni druge (Gleason, 2005). Jedna od uticajnijih teorija iz ovog pravca istraživanja jeste Longova hipoteza o interakciji (1980), kojom se ističe struktura interakcije, odnosno to da pregovaranje značenja u vidu modifikovanog inputa $\mathrm{i}$ interakcije (npr. ponavljanje, traženje potvrde o razumevanju, provera razumevanja, traženje pojašnjenja i sl.) dovodi do boljeg razumevanja, a samim tim, u konačnom ishodu, i do usvajanja jezika (Long, 1980, 1992). Pored Longa i drugi istraživači su sprovodili istraživanja na osnovu navedene hipoteze (za pregled v. Pica, 1994). Neke od ovih studi-

\section{Eng. Monitor Model.}

14 Razumljiv input može se povezati sa idejom zone narednog razvoja L. Vigotskog (Vigotski, 1974). U pitanju je zona koja obuhvata razliku između trenutnog razvojnog nivoa (npr. u usvajanju jezika), odnosno onoga što osoba može da uradi samostalno, i očekivanog narednog razvojnog nivoa, odnosno onoga što osoba trenutno može da uradi uz pomoć kompetentnije osobe (npr. kompetentnijeg govornika datog jezika). 
ja predstavljaju direktan pokušaj da se utvrdi veza između interakcijskih modifikacija, pre svega pregovaranja značenja, i povećanja razumevanja sadržaja. Na primer, istraživanje koje su sproveli Pica, Young, \& Doughty (1987), jedno je od onih koja su pokazala da su interakcijske modifikacije efektnije za bolje razumevanje inputa nego same lingvističke modifikacije (u smislu pojednostavljenja kompleksnosti inputa).

Brojna interakcijska istraživanja su i kasnije pokušala da utvrde vezu između modifikovanog inputa, interakcije i usvajanja stranog jezika. U takvim istraživanjima ispitanici obično dobijaju input koji je modifikovan (npr. gramatički pojednostavljen) ili nemodifikovan (uz eventualno ponavljanje ključnih reči neophodnih za razumevanje), pri čemu u nekim slučajevima mogu i da postavljaju pitanja ili na drugi način uspostavljaju interakciju sa sagovornicima ${ }^{15}$. Neke studije su uspele da uspostave vezu između interakcijskih modifikacija sa povećanjem razumevanja sadržaja, ali ne i sa usvajanjem (npr. Loschky, 1994; Gass \& Varonis, 1994), dok su druga utvrdila i stabilnije efekte. Mackey (1999) je u svojoj studiji, na primer, pokazala da je u usvajanju upitnih reči u engleskom jeziku naprednija bila grupa koja je postavljala pitanja, odnosno uspostavljala interakciju sa svojim sagovornicima.

Rezultati nekih od ovih studija mogu se protumačiti i kao potvrda ideje da je unutar interakcije produkcija ta koja je doprinela boljem usvajanju određene gramatičke jedinice. Pojedini istraživači (npr. Swain, 1985) su stoga vrlo rano pomerili fokus na produkciju (eng. output). Većina autora, $u$ interakcijskom pristupu i šire, saglasna je u tome da je produkcija neophodna za poboljšanje fluentnosti govora i da učenici moraju vežbati produktivne veštine kako bi počeli da koriste međujezički sistem rutinski i kako bi bili primorani da se pored značenja fokusiraju i na gramatičke elemente. Drugim rečima, produkcija je neophodna za usvajanje usled toga što, za razliku od razumevanja, ne može biti zasnovana samo na značenju. Svejnina hipoteza o produkciji (Swain, 1985, 1995) ističe da pored uvežbavanja gramatičkih struktura, produkcija ima i funkciju opažanja (usmeravanja pažnje), funkciju testiranja hipoteza i metalingvističku funkciju. Autorka se fokusira na mogući značaj koji međujezik koji vršnjaci koriste u međusobnoj komunikaciji može imati na usvajanje jezika (Swain, 1995). Drugi autori su se bavili direktnijom vezom između produkcije i usvajanja

15 U istraživanjima se porede grupe koje su bile izložene različitim situacijama u pogledu inputa i interakcije. 
jezika. Na primer, Ellis i He (1999) su pokazali da je „produktivna” grupa (koja je imala zadatak da sagovornicima daje instrukcije na osnovu inputa koji su dobili) pokazala bolje rezultate na leksičkom testu, i na receptivnom i produktivnom nivou.

Ukupno gledano, istraživanja u okvirima ovog pristupa pokazala su da efekti interakcije na postignuće zaista postoje i da su i statistički i praktično značajni (Plonsky \& Gass 2011: 331). Detaljnija pregledna istraživanja poput Keck, Iberri-Shea, i dr. (2006) pokazuju da efekti interakcije na usvajanje postoje i za leksičke i za gramatičke fenomene, kao i efekti produkcije. Međutim, treba istaći da pregledne studije uzimaju u obzir i ispitivanja korektivne povratne informacije, koja nisu predmet našeg rada, pa je ove zaključke ipak potrebno uzeti sa određenom rezervom. Takođe, dok postoji određena raznolikost u pogledu jezika koji su ispitivani, ipak jasno dominiraju engleski, španski i donekle japanski jezik (Mackey, 2007).

U pogledu metodoloških pristupa koji se koriste, dok su rana istraživanja u velikoj meri bila zasnovana na posmatranju (Plonsky \& Gass 2011: 330), danas su tipičnije eksperimentalne i kvazieksperimentalne studije, koje se često sprovode u kontekstu učionice, gde je najlakše prilagoditi input i nametnuti učenicima zadatke koji zahtevaju interakciju. Različite studije posvećuju pažnju različitim situacijama, odnosno različitim sagovornicima u interakciji (u učionici ređe izvorni govornik-učenik, češće nastavnik-učenik ili učenik-učenik). Istraživanja su dominantno usmerena ka inputu koji je vezan za konkretne leksičke ili gramatičke pojave (članove, prošlo vreme, postavljanje pitanja, itd.), u odnosu na koje se meri i postignuće, različitim zadacima primerenim za pojave koje se ispituju (na primer, zadatak utvrđivanja razlika između slika za testiranje postavljanja pitanja; Mackey, 1999). U centru pažnje je u daleko većoj meri kvalitet (pre svega vrsta) nego kvantitet inputa, pri čemu se poseban naglasak stavlja na modifikacije, dok se manje pažnje posvećuje autentičnom inputu.

Plonsky i Gass (2011) sprovode detaljnu metaanalizu posvećenu upravo metodologiji istraživanja $i$ analize rezultata $u$ istraživanjima interakcije i ukazuju na postepeni napredak u pogledu rigoroznosti istraživanja, ali i potrebu da se više pažnje posveti instrumentima koji se koriste za merenje relevantnih varijabli i preporučuju pažljivije testiranje njihove pouzdanosti. Ova ujedno zamerka i preporuka može se proširiti na istraživanja odnosa između inputa i postignuća u J2 uopšte, budući da i pregled dat u odeljku 2 ukazuje na nedostatak jasnih i konzistentnih operacionalizacija. 
Gledano sa strane teorije, Mitchel, Myles i Marsden (2013: 185) ističu da su interakcijska istraživanja zasnovana na jasnim tvrdnjama, ali da su te tvrdnje najvećim delom eksplorativne prirode, odnosno ne objašnjavaju kako i zašto dolazi do upravo onakvih uticaja inputa i interakcije na postignuće kakvi se beleže. Šire viđenje jezika na koje se ova istraživanja nadovezuju delom je nativističko (posebno kod Krašena i u Longovim ranijim radovima), a delom kognitivističko (Longovi kasniji radovi). Novija istraživanja postepeno se usmeravaju i u pravcu integracije procesiranja koje se odvija u realnom vremenu tokom interakcije. ${ }^{16}$

\subsection{Modeli procesiranja inputa}

Drugi istraživači pokušali su da ostvare ono u čemu interakcijski pristup i dalje čeka ozbiljniji pomak, da daju teorijski model procesiranja jezika, odnosno da obezbede teoriju učenja kojom bi se objasnilo kako se jezik usvaja na osnovu inputa. Iako su postojeći modeli naizgled u manjoj meri okrenuti ka postignuću, iz njih su proistekli i značajni pedagoški pristupi posvećeni primeni teorijskih modela i empirijskih saznanja u nastavi.

Jedan od najpoznatijih modela jeste teorija procesiranja inputa (VanPatten, 1996, 2002), koja ima za cilj da objasni transformaciju inputa u intejk. U centru pažnje je to kako učenici uspostavljaju veze između forme i značenja jedinica koje susreću u inputu. ${ }^{17}$ Intejk čine analizirane lingvističke informacije koje su proistekle iz inputa i koje se potom čuvaju u radnoj memoriji za dalju obradu (VanPatten, 2002: 757; VanPatten, 2004: 6). Jedno od centralnih pitanja jeste i koje strategije učenici koriste prilikom razumevanja inputa i pod kojim uslovima razumevanje prelazi u usvajanje. Ova teorija se ograničava na jedan uzak deo procesa usvajanja i podrazumeva da se ono što se dalje dešava sa intejkom može objasniti različitim mehanizmima (urođenim kao u generativnoj gramatici, ili nekim drugim). Naglasak je, dakle, na razumevanju inputa, koje mora prethoditi usvajanju, iako ga ne garantuje, jer je usvajanje nemoguće bez uspostavljanja odgovarajućih veza između forme i značenja (VanPatten, 2015).

16 Potrebu za pažljivijim razmatranjem procesiranja ističe, između ostalih, R. Ellis (2015: 165-166), navodeći da se u interakcijskim istraživanjima često govori o implicitnom znanju, dok se zapravo meri eksplicitno znanje.

17 VanPatten definiše procesiranje kao uspostavljanje veza između forme i značenja tokom razumevanja inputa, u realnom vremenu (2004: 6-7). 
Teorija procesiranja inputa pretpostavlja nekoliko principa kojima se učenici rukovode: prednost u obradi se daje značenju, odnosno leksičkim rečima (budući da se preko njih lakše dolazi do značenja); ukoliko je isto značenje iskazano i leksičkim i gramatičkim sredstvima (na primer, prošlo vreme), gramatička sredstva će se obrađivati tek nakon što su leksička obrađena; među gramatičkim jedinicama prednost u obradi će imati ona koja su neredundantna (jedina u rečenici iskazuju dato značenje); gramatičke jedinice koje se ne mogu jasno povezati sa nekom značenjskom kategorijom (npr. veznik that) obrađuju se kasnije od onih koje imaju jasno značenje; u pogledu izgradnje sintaksičke strukture, prva imenička reč koja se susretne tumači se kao subjekat rečenice (uz određene izuzetke, ako postoje dodatne kontekstualne informacije koje čine ovaj princip očito pogrešnim). Naravno, mera primene ovih principa zavisi i od nivoa znanja, ali važno je primetiti da oni često ne vode ispravnoj analizi inputa.

Iz ove teorije nastao je pedagoški pristup zasnovan na vođenom procesiranju (eng. processing instruction), koji podrazumeva rad na izmeni strategija koje učenici koriste prilikom početne obrade inputa (v. npr. VanPatten \& Cadierno, 1993; Wong, 2004). Primena ovog pristupa odvija se tako što učenici nakon eksplicitnog objašenjenja gramatičke pojave i adekvatnih strategija za obradu inputa ${ }^{18}$ bivaju izloženi strukturiranom inputu vezanom za datu pojavu, uz zadatke razumevanja koji su formulisani tako da navode na adekvatne, a ne na preferirane strategije. Lee i Benati (2009: 48) navode kao primer čitanje rečenica sa glagolima u sadašnjem i prošlom vremenu, bez vremenskih priloga, gde bi učenici samo na osnovu glagola morali da odrede kada se radnja dešava. Produkcija se u ovom pristupu smatra kasnijom fazom i ne podstiče se odmah.

Lee i Benati (2009) daju detaljan pregled istraživanja koja primenjuju vođeno procesiranje i zaključuju da centralnu komponentu koja ključno doprinosi postignuću predstavlja strukturirani input. Naime, rezultati empirijskih istraživanja pokazuju da nema razlike u postignuću između učenika koji su izloženi i eksplicitnim objašnjenjima i strukturiranom inputu i onih koji su dobili samo strukturirani input, dok je postignuće niže kod učenika koji su izloženi samo eksplicitnim objašnjenjima. Isti autori zaključuju i da ovaj pristup daje bolje rezultate od pristupa u nastavi koji su više okrenuti ka produkciji, čak i kada se testira produkcija. Jezici koji-

18 Na primer, za jezike sa slobodnijim redom reči napomenulo bi se da prva imenica u rečenici nije uvek subjekat. 
ma se istraživanja najviše bave su engleski, španski, italijanski, francuski i japanski, a ispitivani nivoi znanja su uglavnom početni i srednji. Takođe se pokazalo da intervencije u nastavi mogu sa podjednakom uspešnošću da se sprovode putem Interneta i da se javljaju dugoročni efekti na postignuće.

Još jedan nastavni pristup koji se može povezati sa odgovarajućim teorijskim modelom zasniva se na naglašavanju inputa (eng. input enhancement; v. Sharwood Smith, 1993), na primer vizuelnim sredstvima poput podvlačenja, upotrebe različitih boja i slično (v. i Benati, 2016, 2017). Empirijska istraživanja odnosa naglašenog inputa i postignuća ne ukazuju uvek na povezanost (v. pregled u Lee \& Huang, 2008; up. i Lee \& Benati, 2009, gde se ističe da za strukturiran input nije bitno da li je naglašen ili ne). Međutim, Sharwood Smith i Truscott (2014) objašnjavaju nedoslednost $\mathrm{u}$ rezultatima nedovoljno jasnim početnim pretpostavkama, usled nedostatka adekvatnog teorijskog okvira. Ovi autori predlažu kao teorijski okvir i kao širi model procesiranja inputa model nazvan MOGUL (eng. Modular On-line Growth and Use of Language), zasnovan na ideji o modularnom kognitivnom sistemu, kao i modularnom razvoju i procesiranju jezika. U ovom modelu pretpostavlja se da se obrada inputa odvija u više stadijuma i putem više kognitivnih modula (gde su jezička znanja podeljena između specijalizovanog jezičkog modula i modula za opšta znanja), usled čega isti načini naglašavanja inputa ne dovode uvek do istih rezultata niti do slične brzine usvajanja. Drugim rečima, potrebno je utvrditi koje pojave u J2 mogu da se usvoje putem specijalizovanog jezičkog modula, a za koje se koriste opštija znanja - od toga će zavisiti izbor načina na koji input najbolje može da se predstavi, a on će svakako biti potrebniji, uz više uvežbavanja, tamo gde je neophodna upotreba opštih znanja (Whong, 2011: 91). Marsden, Whong, i Gil (2018), na primer, koriste MOGUL u ispitivanju usvojenosti engleskog markera polarnosti any 'neki, ijedan' i pronalaze pozitivan efekat eksplicitnog inputa, ali i naznake usvojenosti pravila koja nisu bila zastupljena u inputu, za koja pretpostavljaju da su usvojena putem specijalizovanog jezičkog modula, odnosno pod uticajem univerzalne gramatike.

Donekle sličan model procesiranja jezika koji se bavi fazama koje prate intejk ponuđen je u teoriji autonomne indukcije (Caroll, 1999, 2001). U pitanju je prvi kompleksniji model koji pokušava da uključi jezičke predstave (eng. representation), procesiranje i učenje (Mitchel, Myles, \& Marsden, 2013: 58). Autorka posebno naglašava razliku između razume- 
vanja i usvajanja, i inputa koji je potreban za ova dva procesa (Carroll, 1999: 365): jezik se različito procesira u svrhu analiziranja iskaza i usvajanja novih lingvističkih sadržaja. Do učenja dolazi kada se pojavi problem sa procesiranjem (koje je prvobitno zasnovano na mehanizmima prenetim iz maternjeg jezika), odnosno onda kada input na stranom jeziku ne može da se obradi postojećim procedurama - tada se pokreće urođeni mehanizam za usvajanje jezika. Ova teorija za sada nije našla značajnu direktnu primenu u učionici, ali pored zasluga za obuhvatnost, mora joj se priznati i značaj za bliže definisanje pojma inputa.

Za razliku od interakcijskih, pristupi zasnovani na procesiranju ne predstavljaju jedinstvenu širu celinu, između ostalog zbog toga što su deo različitih opštijih modela usvajanja jezika. Međutim, kada se pogleda njihova primena u usvajanju $\mathrm{J} 2 \mathrm{u}$ učionici, kroz vođeno procesiranje i naglašavanje inputa, metodološki postupci su velikim delom slični onima $\mathrm{u}$ interakcijskim istraživanjima: dominantno se koriste eksperimentalne i kvazieksperimentalne studije sprovedene kroz izlaganje učenika različitim vidovima prilagođenog inputa, uz eventualno poređenje sa situacijama $u$ kojima je input odsutan.

\subsection{Drugi pristupi}

Pristupi koji značajnu pažnju pridaju odnosu inputa i postignuća, a ne spadaju u gore navedene celine, mogu se podeliti na one u čijem fokusu je detaljnije ispitivanje količine i kvaliteta inputa i one koji input posmatraju u sprezi sa drugim faktorima.

U izučavanju dvojezičnosti često se ističe da bilingvalni govornici u poređenju sa monolingvalnim srazmerno manje dolaze u kontakt sa inputom po jeziku (v. npr. Unsworth, 2016), pa ne iznenađuje to što se velika pažnja poklanja utvrđivanju opšte količine inputa u svakom od jezika koje dvojezični govornici usvajajaju. Međutim, ova istraživanja su najvećim delom fokusirana na simultanu dvojezičnost, odnosno paralelno usvajanje dva maternja jezika na ranom uzrastu. ${ }^{19} \mathrm{U}$ usvajanju stranog jezika, posebno kada se govori o odraslim učenicima, situacija je nužno drugačija. Naime, budući da je maternji jezik već u potpunosti usvojen, ne može se na isti način govoriti o podeljenosti inputa, već samo o tome šta predstav-

19 Izuzetno velik broj radova bavi se efikasnošću različitih instrumenata za merenje količine inputa u simultanom dvojezičnom usvajanju (v. npr. zbornik radova Input and Experience in Bilingual Development, koji su priredile Grüter \& Paradis, 2014). 
lja dovoljnu, a šta dostupnu količinu inputa za usvajanje J2. Usled velikog broja različitih konteksta, teško je dati čak i okvirnu procenu (v. YoungScholten \& Piske, 2009: 13), ali preovlađujući stav jeste da učenici J2 ne dobijaju ni približno jednaku količinu inputa kao deca tokom usvajanja maternjeg jezika (gde procena iznosi 9.000 sati inputa do navršenih pet godina života), čak ni kada žive u sredini gde se J2 govori (Sharwood Smith, 1994). Za kontekst učionice se posebno često sreću tvrdnje o „ekstremnoj ograničenosti” dostupnog inputa (v. O'Grady, 2003: 58).

Fokus $\mathrm{u}$ istraživanjima $\mathrm{J} 2$ stoga je $\mathrm{u}$ većoj meri na odlikama inputa $\mathrm{s}$ obzirom na konkretne manje jezičke jedinice. Jedan od pristupa koji veliki značaj pridaju količini i kvalitativnim odlikama inputa jeste kognitivističko viđenje usvajanja J2. Ovo viđenje zasnovano je na detaljno razrađenim opštim teorijama asocijativnog učenja (v. npr. Ellis, 1998). Kognitivisti smatraju da usvajanje $\mathrm{J} 2$ u prirodnom okruženju i u učionici predstavljaju u osnovi slične procese zasnovane na istim principima analize inputa, $s$ tim što u učionici proces usvajanja može biti ubrzan nastavom (v. npr. Ellis, 2002a) ${ }^{20}$ Prema njihovom viđenju, ne postoje urođeni jezički mehanizmi, pa input predstavlja početnu tačku usvajanja. Proces usvajanja se, shodno tome, posmatra kao proces statističke generalizacije iz uzoraka inputa (Ellis, 2009: 139).

Među odlikama inputa koje presudno utiču na usvajanje izdvajaju se učestalost jezičkih jedinica, njihova forma (pre svega uočljivost; eng. salience), njihova funkcija (koliko su značajne za razumevanje i koliko su tipične) i interakcija između forme i funkcije (Ellis \& Collins, 2009). Kod učestalosti se pokazuje da na postignuće utiču i pojedinačna ili frekvencija tokena (eng. token frequency) i tipska frekvencija (eng. type frequency). Prva označava koliko se često određeni oblik javlja u inputu (npr. broj ditranzitivnih konstrukcija u odgovarajućem korpusu), dok druga predstavlja broj različitih leksičkih jedinica koje se javljaju u okviru neke konstrukcije (npr. broj različitih glagola koji se u nekom korpusu javljaju u ditranzitivnim konstrukcijama). Visoka pojedinačna frekvencija doprinosi lakšem percipiranju konstrukcije, dok je visoka tipska frekvencija neophodna za uočavanje produktivnosti (Bybee, 2008; Ellis, 2009). Idealnom situacijom za učenje smatra se ona u kojoj se učenici prvo upoznaju sa manjim bro-

20 Kognitivistički pristupi mogli bi se prema nekim od svojih viđenja svrstati u prethodni odeljak. Međutim, ovde ih odvajamo usled toga što preostali pristupi fokusirani na procesiranje ne podrazumevaju emergentističko viđenje jezika (već pretežno nativističko) i ne fokusiraju se na merenje učestalosti jezičkih jedinica u inputu. 
jem tipičnih primera neke konstrukcije (npr. glagolima koji se često javljaju u ditranzitivnim konstrukcijama), a zatim se početni skup proširuje kako bi se utvrdila produktivnost konstrukcije. ${ }^{21}$ Empirijska istraživanja koja na ovo ukazuju najčešće su zasnovana na poređenju više različitih eksperimentalnih manipulacija učestalosti u inputu, pri čemu se često koriste izmišljene jezičke jedinice, kako bi istraživači bili sigurni da ih ispitanici ne poznaju (v. npr. Goldberg, Casenhiser, \& Sethuraman, 2004). Takođe se koriste podaci iz korpusa učeničke produkcije (Ellis \& Ferreira-Junior, 2009; Römer, Skalicky, \& Ellis, u štampi).

Međutim, kao što ističe Ellis (2002a: 178), „učestalost nije dovoljna kao objašnjenje, inače se nikada ne bismo odmakli dalje od određenog člana". ${ }^{22}$ Prilikom razmatranja usvajanja potrebno je uzeti u obzir i druge odlike inputa. Naglasak na uočljivosti vezan je za činjenicu da je neke jezičke jedinice lakše uočiti u inputu od drugih. Na primer, leksičke reči su uočljivije od gramatičkih, pa će učenici usled toga pre primetiti na primer vremenske priloge, nego glagolske morfeme kojima se iskazuje prošlo vreme (Ellis \& Collins, 2009; up. i VanPattenove prinicipe procesiranja inputa iz odeljka 3.2). Kognitivističko viđenje značajno je za proučavanje inputa ne samo zbog postojanja šire teorije koja objašnjava i kako se input obrađuje, već i zbog toga što govori o situacijama koje posebno pogoduju usvajanju, a koje se kroz prilagođavanje inputa relativno lako mogu primeniti u učionici, podešavanjem učestalosti, isticanjem manje uočljivih jedinica i slično.

Najzad, u pogledu ispitivanja odnosa inputa i drugih faktora koji utiču na usvajanje jezika u višejezičnom kontekstu, primećuje se zastupljenost uticaja maternjeg jezika (v. npr. Miličević, 2007), nivoa znanja i drugih kognitivnih faktora (v. pregled u Ellis, 2002b). Međutim, u širem društvenom kontekstu, upadljiv je nedostatak istraživanja posvećenih stranom jeziku. Za simultanu dvojezičnost je pokazano da je input dovoljan za uspešno savladavanje jezika kao deo složenog sistema, koji uključuje i

21 Istraživanja pokazuju da kod većine konstrukcija postoji relativno mali broj leksičkih jedinica koje se u njima javljaju vrlo često i relativno velik broj leksičkih jedinica koje se javljaju retko (sledeći Zipfovu raspodelu; Ellis, 2009). Zanimljivo je uočiti i da je ovaj pristup odavno implicitno pristutan u pedagoškim materijalima, pa se na primer imeničke deklinacije tipično predstavljaju putem nekoliko čestih imenica odgovarajućeg tipa.

22 "[...] frequency is not a sufficient explanation; otherwise we would never get beyond the definite article in our speech" 
stavove, vrednosne sisteme i društvene prilike koji imaju funkciju usklađivanja količine dostupnog i potrebnog inputa. Na primer, Pearson (2007: 400) tvrdi da je količina inputa faktor nad kojim roditelji ili društvena zajednica imaju najveću kontrolu. ${ }^{23}$ Ova autorka predlaže teorijski „,model cikličnosti”, koji uključuje input, ovladavanje jezikom i upotrebu (eng. input-proficiency-use cycle). Prema modelu, što govornici više koriste jezik, to više inputa „traže”; veća količina inputa dovodi do većeg uspeha u korišćenju jezika; češća upotreba „traži” više inputa, pa ciklus kreće ispočetka. Međutim, ovakav ciklus ne postoji u vakuumu već i drugi faktori značajno određuju količinu inputa i nivo usvojenosti: uzrast početka učenja jezika (pod pretpostavkom da što ranije počne da se uči jezik, to je stepen ovladavanja veći, a veća uspešnost dovodi do češće upotrebe), stavovi roditelja, braće, sestara i vršnjaka doprinose boljem prihvatanju jezika i samim tim utiču na češću upotrebu, čime podspešuju efikasnost ciklusa (str. 401). Model cikličnosti može naći primenu i u kontekstu usvajanja stranog jezika; međutim, svakako zahteva empirijsku proveru.

Što se tiče stranog jezika, prema nekim autorima input je takođe smisleno ispitivati samo u sprezi sa drugim faktorima koji su se pokazali kao važni za usvajanje (v. Grubor, 2012, 2018). Grubor (2012) je pokazala da faktor namere i emocija (FNE), kao jedna od komponenti stava, predviđa dve mere postignuća u engleskom (prosečnu ocenu sa oko $30 \%$ i ocenu na eksternom testu sa skoro 45\%), što je u skladu da teorijom namernog ponašanja (eng. theory of planned behaviour). Dakle, prema ovom istraživanju stavovi indirektno preko namere utiče na postignuće, dok input pripada složenom faktoru jezičkog okruženja, koji je jedan od pretpostavljenih faktora koji utiču na formiranje stavova prema OKLD modelu (Grubor, 2018). ${ }^{24}$ Veza između stava i konkretno vannastavnog inputa ustanovljena je kod srednjoškolske populacije, kod koje je utvrđena proporcionalna povezanost između ukupne količine vannastavnog inputa i generalnog stava ispitanika (veza je još jačeg intenziteta sa FNE). Dakle, stavovi jesu povezani sa inputom (u ovom slučaju vannastavnim), ali je teorijska pretpostavka drugačija od gorepomenutog cikličnog modela. Naravno, s obzirom da je tema prvog

23 Treba imati na umu da su ispitanici njene studije mala deca, te da u širem kontekstu možemo očekivati ovakav uticaj u kontekstu J2 i od nastavnika, pa i vršnjaka, ali i veći uticaj drugih faktora (v. Grubor, 2012).

24 Teorijski OKLD model formiranja stavova uključuje obrazovnu, kulturnu, ličnu i društvenu dimenziju (v. Grubor, 2018). 
navedenog istraživanja stav prema učenju J2 i njegova veza sa postignućem (2012), a ne (in)direktna veza postignuća i izloženosti ciljnom jeziku, ne možemo tvrditi sa sigurnošću da takva veza (ne) postoji. Ono što je izvesno jeste da su input i stav povezani, što nam potvrđuju rezultati druge studije (2018). Pretpostavka je da je ova veza dvosmerna: količina izloženosti engleskom jeziku utiče na oblikovanje stavova prema učenju jezika, i izgledno je da stavovi zatim imaju povratno dejstvo na količinu inputa, u smislu da učenici žele da stupaju dalje u kontakt sa sadržajima prema kojima imaju pozitivan stav, što u osnovi odgovara ideji B. Pearson.

Prikazom radova čiji je fokus na statističkim odlikama inputa i opštim kognitivnim mehanizmima i radova sa socijalnopsihološkom orijentacijom, zaokružujemo pregled različitih pristupa proučavanju uloge inputa u usvajanju stranog jezika. Ukupno gledano, stiče se utisak da je tematska raznovrsnost prikazanih istraživanja veća od njihove metodološke raznovrsnosti, budući da se i u vrlo različitim teorijskim pristupima input i postignuće mere na slične načine. Međutim, nije teško uočiti da i teorijska i metodološka strana ostavljaju prostora za brojna nova istraživanja.

\section{Input i postignuće u učionici: Kuda dalje?}

Činjenica da poddisciplinu primenjene lingvistike koja se bavi usvajanjem J2 ne karakteriše zajednička teorija, već veliki broj različitih pristupa, vrlo se jasno ogleda u istraživanjima inputa. $\mathrm{Na}$ osnovu datog pregleda primećujemo da određeni pristupi sprovode istraživanja u okviru širih teorija (kognitivističke i nativističke), drugi indirektno počivaju na širim teorijskim okvirima (npr. sociokulturnoj teoriji Vigotskog, što je slučaj kod Krašenove hipoteze o inputu i interakcijskih istraživanja, ili nativizmu, kao kod procesiranja inputa), ali i da postoje istraživanja gde za polaznu osnovu nisu toliko značajne opšte teorije učenja (v. ispitivanje količine inputa u simultananoj dvojezičnosti). S obzirom na naglašenu teorijsku podeljenost oblasti, nerealno je očekivati da će se istraživanja inputa uskoro steći u jedinstvenom okviru. Međutim, može se težiti saradnji u domenu merenja inputa, postignuća i njihovog međusobnog odnosa, budući da su brojni konstrukti suštinski neutralni i primenljivi u različitim teorijskim pristupima. Takođe bi bilo zanimljivo uporediti različite kontekste usvajanja jezika (simultana dvojezičnost, drugi jezik, strani jezik) i proveriti da li je uloga inputa stabilna ili varira u zavisnosti od konteksta u kome se jezik uči. Ovakav podatak bi mogao pomoći u donošenju odluka pri jezičkom 
planiranju, izradi nastavnih planova i programa, pa i izboru konkretnih nastavnih materijala i metoda.

S tim u vezi, mišljenja smo da je neophodno i generalno pomeranje paradigme ka kompleksnijim modelima inputa, gde se ne ispituje samo direktan odnos inputa sa postignućem, već se uzima u obzir više faktora istovremeno. Kao što neki autori predlažu (Pearson, 2007; Unsworth, 2016; Grubor, 2018), treba uzeti u obzir šire društveno okruženje i okolnosti koje prate usvajanje jezika (u smislu od koga dolazi input, kog kvaliteta, u kojoj meri...). Jedan od predloženih kompleksnih modela „,input-ovladavanje jezikom-upotreba" (Pearson, 2007), koji čeka empirijsku potvrdu u kontekstu J2, podrazumeva da input operiše u sprezi sa ostalim faktorima (uzrastom, stavovima, produkcijom). Ovakvo viđenje stavlja input u jedan složen sistem, što usvajanja jezika svakako jeste, jer informacije koje dobijamo iz svog okruženja (bilo u obliku jezičkog inputa ili uverenja o značaju nekih sadržaja, na primer) mogu uticati na spremnost individue da se upusti u različite oblike jezičkog ponašanja, što ima funkciju uvežbavanja sadržaja, ali istovremeno i oblikovanja stavova prema sadržaju. Navedeni model je vezan za simultani bilingvalizam, ali ima potencijala da bude iskorišćen u kontekstu usvajanja stranog jezika jer postoje istraživanja koja su pokazala uticaj stavova na jezičko ponašanje (v. Grubor, 2012).

U metodološkom smislu, neophodno je pre svega težiti rigoroznijem merenju inputa i postignuća (v. Grüter, Hurtado, i dr., 2014). Sa jedne strane, to znači osmišljavanje novih načina operacionalizacije ukupne količine inputa i opšteg postignuća, gde se za uzor mogu uzeti brojna istraživanja ovih mera u kontekstu simultane dvojezičnosti. Sa druge strane, kao što smo videli u pregledu, najveći broj radova kao meru postignuća uzima uspeh u savladavanju neke konkretne gramatičke ili leksičke jedinice, iako se u savremenom školstvu sve više insistira na jezičkim veštinima i kompetencijama, a ne znanjima per se. Takođe, potrebno je posvetiti više pažnje vannastavnom inputu i zajedničkom sagledavanju uticaja modifikovanog inputa koji se dobija u nastavi i autentičnog inputa iz drugih izvora. Ovde bi se mogla u većoj meri iskoristiti raspoloživost referentnih korpusa brojnih jezika, za čiji sadržaj se može pretpostaviti da u pogledu konkretnih jezičkih pojava aproksimira, odnosno približno odgovara inputu kojem su učenici izloženi van učionice. Najzad, bitno je naglasiti i da su poželjne longitudinalne studije kojima se stepen usvojenosti J2 s obzirom na input može pratiti tokom dužeg vremenskog perioda. 
U skladu sa svim navedenim razmatranjima, slažemo se i sa autorima koji insistiraju na primenjivanju složenijih statističkih analiza (v. npr. Unsworth, 2016) umesto uobičajenih korelacionih i jednofaktorskih (kvazi)eksperimentalnih studija. Složenije analize jedine mogu dati jasniju sliku o mestu koje input zauzima u složenom procesu usvajanja J2.

\section{Input u usvajanju J2: Zaključne napomene}

Značaj inputa u usvajanju $\mathrm{J} 2$ je nesumnjiv, bez obzira na teorijsku orijentaciju istraživača. Na osnovu detaljnog uvida u literaturu stiče se utisak da je broj radova posvećenih inputu proporcionalan značaju koji on ima za usvajanje J2: ne samo da sve opštije teorije uključuju shvatanja o značaju i načinu delovanja inputa, već postoje i pristupi kojima su u centru pažnje upravo input i proces njegovog opažanja i pretvaranja u nova znanja. Međutim, i pored velikog broja uvida iz svih pravaca istraživanja, i danas postoje brojne teme vezane za input o kojima se nedovoljno zna i koje zavređuju dalje proučavanje. Ovakve teme prvenstveno uključuju preciznije definisanje količine i vrste inputa koja je učenicima stranog jezika potrebna i koja najefikasnije vodi do postignuća. U oblasti usvajanja stranog jezika naročito nedostaju studije koje bi ispitivale utvrđivanje praga nakon koga izostaju dalji značajni napreci u usvajanju ciljnog jezika, po uzoru na istraživanja u kontekstu simultanog bilingvalizma.

Još jedna tema o kojoj se nedovoljno zna a koja se nameće svojim značajem je interakcija inputa sa drugim faktorima - individualnim i faktorima okruženja, maternjim jezikom i nivoom znanja J2, kao i vrsta uticaja koji input ima na postignuće (direktan ili indirektan). Bez obzira na mesto koje input zauzima u okviru nekog teorijskog pristupa, razumno je pretpostaviti da može uticati na postignuće jedino u konstelaciji sa drugim faktorima, koje bi trebalo obuhvatiti u okviru kompleksnih modela usvajanja stranog jezika. Takođe je važno istaći da se često zanemaruju jezičke veštine, ali i uloga vannastavnog inputa u ispitivanjima, iako je realno očekivati da nastavni i vannastavni input kombinovanim efektom utiču na stepen ovladavanja jezikom. Najzad, u skladu sa temom našeg rada, neophodno je naglasiti da ,postoje različite vrsta znanja kojima učenik može da iskaže svoje poznavanje J2" (Gass \& Selinker, 2008: 241) ${ }^{25}$, te da treba

25 "There are a number of ways in which one can represent second language knowledge" 
imati na umu ove razlike i prilikom osmišljavanja istraživanja (poštovati generalni istraživačko-naučni princip kompatibilnosti mere i sadržaja), ali i pri interpretaciji rezultata (razmotriti vrstu znanja i uticaj određene vrste inputa, ili određenih odlika inputa). ${ }^{26}$

Na samom kraju, važno je napomenuti da input predstavlja temu u kojoj bi dodirne tačke između teorije usvajanja J2 i metodike nastave jezika trebalo da budu najdirektnije. Međutim, kako R. Ellis i Shitani (2014: 163, 164) navode na osnovu uvida u veliki broj aktuelnih udženika metodike nastave, većina njih ne uključuje input kao odrednicu, te se stiče utisak da input ne pripada vodećim temama pedagoških priručnika. Naravno, kao što i sami autori navode, bez obzira na nastavnu metodu ili pristup, učenici su izloženi (usmenom i pisanom) inputu koji dolazi od nastavnika, drugih učenika i nastavnih materijala. S tim u vezi, možemo da se složimo sa ovim autorima i ukažemo na neophodnost informisanja nastavnika i budućih nastavnika (studenata filoloških fakulteta) o važnosti ove varijable pri usvajanju stranog jezika. Pored edukativnog značaja, na osnovu našeg prikaza možemo dodati da istraživanja iz ovog pregleda mogu naći svoje mesto $u$ nastavi stranih jezika. Kognitivistički pristupi orijentisani ka procesiranju jezika, na primer, mogu naći direktnu primenu u nastavi (npr. dosta istraživano navođeno procesiranje koje daje jasne odrednice kako se učenici vode kroz proces usvajanja neke nastavne jedinice); oni orijentisani ka frekvencijama, mogu naći direktnu primenu pri osmišljavanju nastavnih materijala, uzimajući u obzir odlike inputa navedene u ovom radu. Sa druge strane, socijalna perspektiva pridaje značaj faktorima okruženja, i naglašava konstrukte poput stavova, te u tom smislu nastavnici mogu da rade na oblikovanju i negovanju stavova učenika prema jeziku i učenju stranog jezika. Interakcijska istraživanja ohrabruju različite oblike interakcije i pregovaranje značenja, što učenicima može pomoći pre svega u boljem razumevanju nastavnih sadržaja. Sve u svemu, implikacije za nastavu radova koji se bave ispitivanjem inputa jasnije su i direktnije nego kod većine drugih tema, što je prvi korak u premošćavanju jaza između teorije i prakse.

26 Ellis, Loewen, i dr. (2009), na primer, smatraju da je neophodno razviti operacionalni okvir koji će istraživačima pružiti izbor mera, zbog čega identifikuju sedam ključnih kriterijuma diferencijacije između implicitnog i eksplicitnog znanja, i na osnovu njih predlažu konkretne testove za merenje ove dve vrste znanja. Navedeno je primenljivo i na sve ostale vrste znanja. Pored različitih vrsta znanja (npr. deklarativno/proceduralno, intencijalno/incidentalno itd.), takođe se ističe značaj i psiholingvističkih konstrukata, kao što su pažnja, radna memorija i sl. (Gass \& Selinker, 2008). 
Maja P. Miličević Petrović / Jelena V. Grubor

\section{LITERATURA}

Benati, A. (2017). The role of input and output tasks in grammar instruction: Theoretical, empirical and pedagogical considerations. Studies in Second Language Learning and Teaching, 7, 377-396.

Benati, A. (2016). Input manipulation, enhancement and processing: Theoretical views and empirical research. Studies in Second Language Learning and Teaching, 6, 65-88.

Bley-Vroman, R. (1990). The logical problem of foreign language learning. Linguistic Analysis, 20, 3-49.

Bowers, E. P., \& Vasilyeva, M. (2011). The relation between teacher input and lexical growth of preschoolers. Applied Psycholinguistics, 32, 221-241.

Butler, Y. G., \& Lee, J. (2006). On-task versus off-task self-assessment among Korean elementary school students studying English. The Modern Language Journal, 90, 506-518.

Bybee, J. (2008). Usage-based grammar and second language acquisition. In P. Robinson \& N. C. Ellis (eds.), Handbook of Cognitive Linguistics and Second Language Acquisition (pp. 216-236). New York: Routledge.

Carroll, S. (2001). Input and Evidence: The Raw Material of Second Language Acquisition. Amsterdam: John Benjamins.

Carroll, S. (1999). Putting 'input' in its proper place. Second Language Research, $15,337-388$.

Carroll, S., \& George, A. (2018). What absolute beginners learn from input: from laboratory to classroom research. ISLA, 2, 112-136.

Chaudron, C. (1985). Intake: On models and methods for discovering learners' processing of input. Studies in Second Language Acquisition, 7, 1-14.

Chomsky, N. (1981). Lectures on Government and Binding. The Pisa Lectures. Dordrecht: Foris Publications.

Collier, V. (1989). How long? A synthesis of research on academic achievement in a second language. TESOL Quarterly, 23, 509-531.

Corder, S. P. (1967). The Significance of Learners' Errors. International Review of Applied Linguistics in Language Teaching, 5, 161-170.

Cvikić, L. (2007). Temeljno nazivlje u usvajanju jezika: hrvatski nazivi za input, output i intake. Lahor, 3, 100-108.

Ellis, N. (2009). Optimizing the input: Frequency and sampling in usage-based and form- focused learning. In M. H. Long \& C. J. Doughty (eds.), The Handbook of Language Teaching (pp. 139-158). Oxford: Blackwell. 
Ellis, N. (2002a). Frequency effects in language processing. A review with implications for theories of implicit and explicit language acquisition. Studies in Second Language Acquisition, 24, 143-188.

Ellis, N. (2002b). Reflections on frequency effects in language processing. Studies in Second Language Acquisition, 24, 297-339.

Ellis, N. (1998). Emergentism, connectionism and language learning. Language Learning, 48, 631-664.

Ellis, N., \& Collins, L. (2009). Input and second language acquisition: The roles of frequency, form, and function. The Modern Language Journal, 93, 329-335.

Ellis, N., \& Ferreira-Junior, F. (2009). Construction learning as a function of frequency, frequency distribution, and function. The Modern Language Journal, 93, 370-385.

Ellis, R. (2015). Understanding Second Language Acquisition. Second edition. Oxford: Oxford University Press.

Ellis, R. \& Shitani, N. (2014). Exploring language pedagogy through second language acquisition research. Abingdon, Oxon: Routledge.

Ellis, R., Loewen, S., Elder, C., Erlam, R., Philp, J., \& Reinders, H. (2009). Implicit and explicit knowledge in second language learning, testing and teaching. Bristol: Multilingual matters.

Ellis, R., \& X. He (1999). The roles of modified input and output in the incidental acquisition of word meanings. Studies in Second Language Acquisition, $21,285-310$.

Friederici, A. D., Steinhauer K., \& Pfeifer, E. (2002). Brain signatures of artificial language processing: evidence challenging the critical period hypothesis. Proceedings of the National Academy of Sciences of the United States of America, 99/1, 529-534.

Gass, S. (2003). Input and interaction. In C. Doughty \& M. Long (eds.), Handbook of Second Language Acquisition (pp. 224-255). Oxford: Blackwell Publishers.

Gass, S. (1997). Input, Interaction, and the Second Language Learner. Mahwah, NJ: Lawrence Elrbaum.

Gass, S., \& Selinker, L. (2008). Second language acquisition: An introductory course. Third edition. New York and London: Routledge.

Gass, S., \& Varonis, E. M. (1994). Input, interaction, and second language production. Studies in Second Language Acquisition, 16, 283-302.

Gathercole, V. M. (2002). Command of the mass/count distinction in bilingual and monolingual children: An English morphosyntactic distinction. In D.K. Oller \& R.E. Eilers (eds), Language and literacy in bilingual children (pp. 175-206). Clevedon, UK: Multilingual Matters. 
Maja P. Miličević Petrović / Jelena V. Grubor

Goldberg, A., Casenhiser, D., \& Sethuraman, N. (2004). Learning argument structure generalizations. Cognitive Linguistics, 15, 289-316.

Grubor, J. (2018). Vannastavni input i stav prema učenju engleskog kao stranog jezika. Primenjena lingvistika, 19 (u štampi).

Grubor. J. (2015). Ispitivanje L2 stavova. Inovacije u nastavi, 28, 140-148.

Grubor, J. (2012). Stavovi prema učenju engleskog kao stranog jezika i njihov uticaj na postignuće (neobjavljena doktorska disertacija). Filološki fakultet, Beograd.

Gleason, J. (2005). The Development of Language. Beijing: World Publishing Corporation.

Grüter, T., Hurtado, N., Marcham, M.A., \& Fernald, A. (2014). Language exposure and online processing efficiency: Relative versus absolute measures. In T. Grüter, \& J. Paradis (eds), Input and experience in bilingual development (pp. 15-26). Amsterdam: John Benjamins.

Grüter, T., \& Paradis, J. (eds.) (2014). Input and Experience in Bilingual Development. Amsterdam: John Benjamins.

Gu, S. (2018). Interaction Process and Chinese EFL Learners' Proficiency Development: A Cognitive and Interactionist Approach. Singapore: Springer.

Gullberg, M., Roberts, L., Dimroth, C., Veroude, K., \& Indefrey, P. (2010). Adult language learning after minimal exposure to an unknown natural language. Language Learning, 60, 5-24.

Horst, M. (2010). How well does teacher talk support incidental vocabulary acquisition? Reading in a Foreign Language, 22, 161-180.

Hulstijn, J. H. (2015). Language Proficiency in Native and Non-Native Speakers. Theory and Research. Amsterdam: John Benjamins.

Jia, G., \& Fuse, A. (2007). Acquisition of English grammatical morphology by native Mandarin-speaking children and adolescents: Age-related differences. Journal of Speech, Language and Hearing Research, 50, 1280-1299.

Johnson, K., \& Johnson, H. (1999). Encyclopedic Dictionary of Applied Linguistics. A Handbook for Language Teaching. Oxford: Blackwell.

Keck, C.M., Iberri-Shea, G., Tracy-Ventura, N., \& Wa-Mbaleka, S. (2006). Investigating the empirical link between task-based interaction and acquisition: A meta-analysis. In J. M. Norris \& L. Ortega (eds.), Synthesizing Research on Language Learning and Teaching (pp. 91-131). Amsterdam and Philadelphia: John Benjamins.

Krashen, S. (1985). The Input Hypothesis: Issues and Implications. Harlow: Longman.

Krashen, S. (1983). Newmark's ignorance hypothesis and current second language acquisition theory. In S. Gass \& L. Selinker (eds.), Language Transfer in Language Learning (pp. 135-153). Rowley, MA: Newbury House. 
Krashen, S. (1982). Principles and Practice in Second Language Acquisition. Oxford: Pergamon.

Kraš, T., \& Miličević, M. (2015). Eksperimentalne metode u istraživanjima usvajanja drugoga jezika. Rijeka: Sveučilište u Rijeci.

Lee, J., \& Benati, A. (2009). Research and Perspectives on Processing Instruction. Berlin: Mouton de Gruyter.

Lee, S-K, \& Huang, H-T. (2008). Visual input enhancement and grammar learning: A meta-analytic review. Studies in Second Language Acquisition, 30, 307-331.

Littlewood, W. (2004). Second language learning. In A. Davies \& C. Elder (eds.), The Handbook of Applied Linguistics (pp. 501-524)

Long, M. (1992). Input, focus on form, and second language acquisition. Paper presented at the American Association of Applied Linguistics Annual Meeeting, Seattle, WA.

Long, M. (1980). Input, Interaction and Second Language Acquisition (unpublished doctoral dissertation). Los Angeles: University of California.

Loschky, L. (1994). Comprehensible input and second language acquisition: What is the relationship? Studies in Second Language Acquisition, 16, 303-323.

Mackey, A. (2007). The role of conversational interaction in second language acquisition. In A. Mackey (ed.), Conversational Interaction in Second Language Acquisition: A Collection of Empirical Studies (pp. 1-26). Oxford: Oxford University Press.

Mackey, A. (1999). Input, interaction and second language development: An empirical study of question formation in ESL. Studies in Second Language Acquisition, 21, 557-588.

Marsden, H., Whong, M., \& Gil, K-H. (2018). What's in the textbook and what's in the mind: Polarity item "any" in learner English. Studies in Second Language Acquisition, 40, 91-118.

Nicoladis, E., Palmer, A., \& Marentette, P. (2007). The role of type and token frequency in using past tense morphemes correctly. Developmental Science, $10,237-254$.

Miličević, M. (2007). The Acquisition of Reflexives and Reciprocals in L2 Italian, Serbian and English (unpublished doctoral dissertation). University of Cambridge, Cambridge, UK.

Mitchell, R., Myles. F., \& Marsden, E. (2013). Second Language Learning Theories. Third edition. Oxon, UK: Routledge.

O'Grady, W. (2003). The Radical Middle. Nativism without language acquisition: Universal Grammar. In C.J. Doughty \& M.H. Long (eds.), The handbook of second language acquisition (pp. 43-62), Malden, USA: Blackwell Publishing Ltd. 
Pearson, B.Z. (2007). Social factors in childhood bilingualism in the United States. Applied Psycholinguistics, 28, 399-410.

Pearson, B.Z., Fernandez, S., Lewadag, V., \& Oller, D.K. (1997). Input factors in lexical learning of bilingual infants (ages 10 to 30 months). Applied Psycholinguistics, 18, 41-58.

Pérez-Leroux, A. T., Pirvulescu, M., \& Roberge, Y. (2009). Bilingualism as a window into the language faculty: The acquisition of objects in Frenchspeaking children in bilingual and monolingual contexts. Bilingualism: Language and Cognition, 12, 97-112.

Pica, T. (1994). Research on negotiation: What does it reveal about second-language learning conditions, processes and outcomes? Language Learning, 44, 493-527.

Pica, T., Young, R., \& C. Doughty (1987). The impact of interaction on comprehension. TESOL Quarterly, 21, 737-758.

Plonsky, L., \& Gass, S. (2011). Quantitative research methods, study quality, and outcomes: The case of interaction research. Language Learning, 61, 325366.

Rankin, T., \& S. Unsworth (2016). Beyond poverty: Engaging with input in generative SLA. Second Language Research, 34, 563-572.

Richards, J. C., \& Rodgers, T. S. (2015). Approaches \& methods in language teaching. Third edition. Cambridge: Cambridge University Press.

Richards, J., \& R. Schmidt (2010). Longman Dictionary of Language Teaching and Applied Linguistics. Fourth edition. Harlow: Pearson Education Limited.

Römer, U., Skalicky, S., \& Ellis, N. (to appear). Verb-argument constructions in advanced L2 English learner production: Insights from corpora and verbal fluency tasks. Corpus Linguistics and Linguistic Theory.

Schmidt, R. (1990). The role of consciousness in second language learning. Applied Linguistics, 11, 129-158.

Sharwood Smith, M. (1993). Input enhancement in instructed SLA. Studies in Second Language Acquisition, 15, 165-179.

Sharwood Smith, M. (1994). Second Language Learning. London: Longman.

Sharwood Smith, M., \& Truscott, J. (2014). Explaining input enhancement: A MOGUL perspective. IRAL, 52, 253-281.

Skinner, B.F. (1957). Verbal Behavior. New York: Appleton.

Slabakova, R., Leal, T. L., \& Liskin-Gasparro, J. (2014). We have moved on: current concepts and positions in generative SLA. Applied Linguistics, 35, 601-606. 
Sundquist, P. (2009). Extramural English matters. Out-of-school English and its impact on Swedish ninth graders' oral proficiency and vocabulary (unpublished doctoral dissertation). Karlstad, University of Karlstad.

Swain, M. (1995). Three functions of output in second language learning. In G. Cook \& B. Seidlhofer (eds.), Principle and Practice in Applied Linguistics: Studies in Honour of H.G. Widdowson (pp. 125-144). Oxford: Oxford University Press.

Swain, M. (1985). Communicative competence: Some roles of comprehensible input and comprehensible output in its development. In S. Gass \& C. Madden (eds.), Input in Second Language Acquisition (pp. 235-253), Rowley, MA: Newbury House.

Thomas, M. (1994). Assessment of L2 proficiency in second language acquisition research. Language Learning, 44, 307-336.

Unsworth, S. (forthcoming). Quantifying language experience in heritage language development. In M. Schmid \& B. Köpke (eds), Input in Second Language Acquisition, Oxford: Oxford University Press.

Unsworth, S. (2016). Quantity and quality of language input in bilingual language development. In E. Nicoladis \& S. Montanari (eds.), Lifespan Perspectives on Bilingualism (pp. 136-196). Berlin: Mouton de Gruyter.

Unsworth, S. (2013). Assessing the role of current and cumulative exposure in simultaneous bilingual acquisition: The case of Dutch gender. Bilingualism: Language and Cognition, 16, 86-110.

VanPatten, B. (2017). Situating instructed language acquisition: facts about second language acquisition. ISLA, 1, 45-60.

VanPatten, B. (2015). Input processing in adult SLA. In B. VanPatten \& J. Williams (eds.), Theories in Second Language Acquisition: An Introduction. Second edition (pp. 113-134). New York \& London: Routledge.

VanPatten, B. (2004). Input processing in SLA. In B. VanPatten (ed.), Processing Instruction: Theory, Research, and Commentary (pp. 5-32). Mahwah, NJ: Lawrence Erlbaum.

VanPatten, B. (2002). Processing instruction: An update. Language Learning, 52, 755-803.

VanPatten, B. (1996). Input Processing and Grammar Instruction in Second Language Acquisition. Norwood, NJ: Ablex.

VanPatten, B., \& Cadierno, T. (1993). Input processing and second language acquisition: A role for instruction. The Modern Language Journal, 77, $45-57$.

Vigotski, L. (1974). Mišljenje i govor. Beograd: Nolit. 
Vygotsky, L. (1991). The Genesis of Higher Mental functions. In P. Light, S. Sheldon, \& B. Woodhead (eds.), Learning to think (pp. 34-63). London: Routledge.

Whong, M. (2011). Language Teaching: Linguistic Theory in Practice. Edinburgh: Edinburgh University Press.

Wong, W. (2004). The nature of processing instruction. In B. VanPatten (ed.), Processing Instruction: Theory, Research, and Commentary (pp. 33-66).

Mahwah, NJ: Lawrence Erlbaum.

Young-Scholten, M., \& Piske, T. (2009). Introduction. In T. Piske \& M. YoungScholten (eds), Input Matters in SLA (pp. 1-26). Bristol: Multilingual Matters.

\title{
Maja P. Miličević Petrović \\ Jelena V. Grubor
}

\section{INPUT AND ACHIEVEMENT IN FOREIGN LANGUAGE ACQUISITION}

\begin{abstract}
Summary
A shared belief that input plays an important role in second language (L2) acquisition is widely held in both theory and practice. Despite prominent divergences in the importance it is assigned in different theoretical frameworks, scholars are in agreement on the fact that no language can be acquired without exposure to input. Accordingly, the objectives of this paper are: to point to some of the common problems researchers encounter as regards explorations into input and its influence on achievement, on the basis of relevant L2 acquisition literature; to propose directions of future research based on the conclusions drawn; and to underline possible implications for foreign language teaching and learning. We conclude that a paradigm shift towards more complex models of input is required with regard to theory, that researchers should strive to apply more methodologically rigorous measurements of input and achievement, and that the results obtained in empirical research should be directly incorporated into textbooks and (pre- and in-service) teacher guides.
\end{abstract}

Key words: achievement, foreign language, input, L2 